\title{
The Pursuit of Excellence in Malaysian Higher Education: Consequences for the Academic Workplace
}

\author{
David W. Chapman ${ }^{1}$, Sigrid Hutcheson ${ }^{2}$, Chang Da Wan ${ }^{3}$, Molly Lee ${ }^{4}$, Ann Austin ${ }^{5}$ \& Ahmad Nurulazam Md. Zain ${ }^{3}$ \\ ${ }^{1}$ Birkmaier Professor of Educational Leadership, University of Minnesota, Minneapolis, Minnesota, USA \\ ${ }^{2}$ Independent Consultant, Minnesota, USA \\ ${ }^{3}$ National Higher Education Research Institute (IPPTN), Universiti Sains Malaysia, Bayan Lepas, Pulau Pinang, \\ Malaysia \\ ${ }^{4}$ Independent Consultant, Penang, Malaysia \\ ${ }^{5}$ Erickson Professor of Higher, Adult and Lifelong Learning, Michigan State University, East Lansing, MI, USA \\ Correspondence: David W. Chapman, Birkmaier Professor of Educational Leadership, University of Minnesota, \\ 211C Burton Hall 178 Pillsbury Dr SE, Minneapolis, Minnesota 55416, USA. Tel: 612-626-8728.
}

Received: May 23, 2017

doi:10.5430/irhe.v2n2p56
Accepted: June 5, 2017

Online Published: June 7, 2017

\begin{abstract}
Over the last twenty years the Malaysian government has put increasing pressure on faculty members at Malaysian universities to increase their research and publication rates, in large part, aimed at increasing the international rankings of Malaysian universities. This study examined the extent to which faculty members believe that this heightened emphasis on research productivity has affected the nature of their work lives and their professional relationships with colleagues and students. The study was grounded in job characteristics theory and on Gappa, Austin, and Trice's (2007) conceptual framework of the "essential elements" in academic work. Data were collected through interviews with 67 faculty members across six universities. Findings indicate that most faculty felt that they had sufficient academic freedom and autonomy, flexibility in their work setting, and professional growth opportunities. However, there was a widespread view that personal performance is disconnected from the financial reward structure, particularly in public universities. Given the compensation structure of public universities, increased research and publications have only limited relationship to financial payoff. This has fueled a widespread view among faculty that the intensified pressures for research and publication are reshaping the nature of their work lives in ways that are not widely welcomed.
\end{abstract}

Keywords: university rankings, incentives, research productivity, career satisfaction

Over the last twenty years, the Malaysian government has made a massive investment in strengthening and expanding its public higher education system and allowed and encouraged the development of private higher education. This investment is driven, in large part, by a widely shared belief that a highly trained workforce will attract business and industry and, with it, international investment. However, these payoffs are only likely to be achieved as international business and industry are aware of the rising quality of Malaysian higher education. The higher education system not only has to be good, but it also has to be widely recognized as good by the international community. A prevalent view among government and university administrators is that this perception of excellence can be accomplished, at least in part, by progressively raising the international rankings of top Malaysian universities. International rankings are one of the most widely recognized signaling devices of university excellence (UNESCO 2014).

One of the most direct ways of raising rankings is through increasing the publication rate of faculty members and graduate students, particularly in top-tier international journals (Chapman and Chien 2015). Consequently, academic staff at top-tier Malaysian universities have come under considerable pressure to increase their rate of scholarly publication in international journals. Universities below that top tier also have introduced policies designed to increase their research profiles, in an effort to move up into top tier status and garner the higher resources the government allocates to top tier universities. 
The Government applied pressure on public universities for greater research productivity through its formulation of the National Five Year Plan for Higher Education, through meetings of Ministry officials with university administrators, through government officials' statements to the media and, most directly, by including rankings as a consideration in the annual budget allocation formula. Private universities, while not subject to quite the same pressures, felt the need to compete as a way of keeping (or growing) their market share of students and instructional staff.

For many Malaysian academic staff, this heightened pressure to publish stands in contrast to their expectations about the nature of academic work, largely centered on teaching, which initially attracted them to a career in higher education. While Azman and Mydin Kutty (2016) illustrated a situation that has many similarities, their study only focused on one research university in Malaysia. Other studies related to academic promotion in Malaysia have also clearly indicated a higher preference and status given to research and publication compared to teaching in promotion exercise in public universities (Azman, Sirat \& Dahalan 2012; Azman et al 2016). Moreover, the increased pressure for publications has not necessarily been accompanied by a reduction in other work expectations (Chapman and Chien 2015). This suggests that academic staff are caught in a bind. In order to continue to enjoy the benefits that have flowed from high levels of government support of higher education they need to increase their publication rates. Yet some academic staff lack the interest or the preparation to engage in the level of research productivity now being expected of them (Chapman and Chien 2015). The shifting job expectations have the potential to lower the career satisfaction of academic staff, potentially creating more tension in the academic workplace and possibly affecting the institutional commitment and loyalty of those staff. To this end, this study examined the manner and extent to which academic staff in selected Malaysian universities believe that the changing external pressures for greater research productivity are affecting the nature of their work lives and their professional relationships with colleagues and students.

This study is part of a larger research project examining the changing pressures on faculty members' work life in Malaysian universities. Previous papers drawing from this data set investigated (1) the efficacy of the incentives available to university administrators for encouraging academic staff to increase their research productivity (Wan et al. 2016) and (2) the extent to which there were differences across institutional types -- public research university, public comprehensive university and private non-profit university -- in the sources of satisfaction and frustration of Malaysian academics (Wan et al. 2015). This study extends from the previous studies to examine the extent to which faculty members believe that the heightened emphasis on research productivity has affected the nature of their work lives and their professional relationships with colleagues and students. This study also contributes to the understanding of academic profession in both public and private universities, as a large proportion of research undertaken on the subject of academic profession (Azman et al. 2014; Azman et al. 2016; Hassan, Tymms \& Ismail 2008; Wan et al. 2016) have focused almost exclusively on public universities. The comparative dimension of this study, both between public and private universities, as well as different types of public universities, have illustrated more nuanced insights about the academic profession. While set in Malaysia, this study addresses an issue of considerable relevance for university administrators, academic staff, and government personnel in many countries. Many university administrators promote higher rankings as a means of attracting external research funding, more qualified students, and stronger faculty members (World Economic Forum 2015). In some countries, governments factor a universities' ranking into funding allocations (UNESCO Institute for Statistics 2014). Indeed, the push for higher university rankings has become an obsession in many countries (Marmolejo 2015; Altbach 2012). In the case of Malaysia, the drive for research has led to the designation of 'Research University' under the Ninth Malaysia Plan (2006-2010), a five-year economic plan, in 2006 (MOE 2014). The obsession with university rankings leading to research and publication pressure was then motivated by the explicit articulation of the National Higher Education Strategic Plan 2007-2020 (Sirat, Azman \& Wan 2017). Hence, a better understanding of how the push for higher university rankings affects the work life of academic staff in Malaysia are relevant to the design of personnel policies and practices in other countries now pursuing a similar path.

\section{Conceptual Framework}

This study draws on Job Characteristics Theory (Faturochman, 1997) and on Gappa, Austin, and Trice's (2007) conceptual framework of the "essential elements" in academic work that relate to faculty members' satisfaction and motivation. Job Characteristic Theory posits that people select occupations, in large part, based on their expectations about the congruence between the nature of the work and their own abilities and interests. When the external environment changes and that congruence erodes, job satisfaction may erode Gappa et al.'s framework suggests the dimensions on which congruence of expectations and personal interests might be examined in the context of university academic staff. Gappa et al's (2007) framework, grounded in an extensive review of empirical research, 
identifies the importance of employment equity, academic freedom and autonomy, flexibility, professional growth, and collegiality as necessary conditions of faculty work. Additionally, they posit that respect is a necessary foundational element cross-cutting all of these other elements. (Gappa, Austin, and Trice 2007: 139). They assert that academic employment in which academic staff feel satisfied involves a reciprocal relationship in which faculty members are treated with fairness and respect, experience these essential elements in their work, and are accorded some measure of security in return for their contributions to the work of the institution.

Employment equity concerns the right of faculty members to be treated fairly in regard to their employment by their department and university. Academic freedom and autonomy refers to the discretion they have in making professional decisions about how they will organize and undertake their work. It includes the right of all faculty members to freely express their views in their teaching and research without institutional censorship, when such views are appropriately and responsibly expressed. Flexibility refers to the ability of faculty members to construct work assignments in ways that best suit the needs of their job and personal life. Professional growth refers to opportunities for faculty members to deepen their knowledge and skills, strengthen their ability to handle challenges, and gain deeper satisfaction from their work. Collegiality refers to faculty members' relationships and rapport with others in the workplace and the extent they feel that they belong to a mutually respectful community of colleagues who are concerned about the well-being of all its members (Gappa, Austin, and Trice 2007: 139-142).

While the Gappa, Austin, and Trice framework is grounded in a largely Western literature on higher education, Austin et al (2014) point out that the Western model of the 'academic career' is widely used as an international norm against which other university systems compare themselves. This comparison is fueled, in part, by the past and current dominance of western universities in the international rankings. A further contributing factor is that many faculty members in Malaysian universities were trained internationally in higher education institutions situated within Western scholarly traditions. Thus, key dimensions of academic work that have been identified as important to faculty within Western contexts are likely to be relevant in studying the faculty experience in Malaysia. This study probes faculty perceptions of such key dimensions of academic work and whether the perceptions of faculty suggest erosion of the quality of their work lives and professional relationships.

\section{Methodology}

A total of 67 interviews were conducted with faculty members across two public research universities, two public regional universities, and two private universities in Malaysia. Universities were randomly selected from the top three highest ranked universities in their category, with one additional condition. To compensate for the possibility that the work environment of universities farther away from the main population center of the country may be meaningfully different from that found in a more urban university setting, the sampling frame required that at least one university of each type be located outside of the Kuala Lumpur area. As discussed by Wan et al (2015), university selection based on rankings poses a challenge, since ranking systems do not necessary coincide. Ranking-based selection drew on a review of the QS Top University Rankings, the QS Top University Rankings-Asia, the Times Higher Education-Asia rankings, the Shanghai Jiao Tong University Academic Rankings of World Universities, and the Webometrics Ranking of World Universities (WRWU) (http://www.webometrics.info/en/world). The reason for including the WRWU, though lesser known, is that it provided a ranking for nearly all Malaysian universities, not just the top institutions. Since no Malaysian university was ranked in the top 400 universities in the Times Higher Education-Asia rankings and only one Malaysian university was ranked in the top 500 world universities in the Academic Rankings of World Universities, sample selection was based heavily on QS-World, QS-Asia, and Webometric rankings.

The sample was developed through a stratified convenience sampling procedure that, while not random, helped ensure a distribution of interviewees by field, rank, and gender. Specifically, within each university, faculty members were categorized as working in STEM (science, technology, engineering, mathematics) or non-STEM fields and further categorized by gender and as junior or senior in their careers, based on their academic rank. Lecturers and Senior Lecturers were grouped as junior faculty; associate and full professors were considered senior. Table 1 reports the distribution of respondents by institutional type, gender and academic rank. 
Table 1. Selected characteristics of the interview sample

\begin{tabular}{lccccccc}
\hline \multirow{2}{*}{$\begin{array}{c}\text { Institutional } \\
\text { type }\end{array}$} & Total & \multicolumn{2}{c}{ Gender } & \multicolumn{2}{c}{ Rank } & \multicolumn{2}{c}{ Discipline } \\
\cline { 2 - 8 } & No. & M & F & Senior & Junior & STEM & Non-STEM \\
\hline Research & 19 & 12 & 7 & 6 & 13 & 10 & 9 \\
\hline Comprehensive & 22 & 12 & 10 & 14 & 8 & 10 & 12 \\
\hline Private & 26 & 16 & 10 & 15 & 11 & 12 & 14 \\
\hline Total & 67 & 40 & 27 & 35 & 32 & 32 & 35 \\
\hline
\end{tabular}

* Senior referred to professors and associate professors; junior included senior lecturers, lecturers and assistant professors

** STEM = science, technology, engineering, mathematics

Interviews focused on the nature of the work experience as perceived by faculty members in higher education institutions in Malaysia. Interviews were conducted by a two-person interview team (an interviewer and a note taker) using an 11 item interview protocol that asked respondents about their employment history in academe, their perceptions of workload, compensation, career advancement opportunities, academic freedom and autonomy, flexibility, opportunities for professional growth, and collegiality, and their observations of changes in the academy and the factors driving those changes. Interviews were recorded and interview notes were checked against recordings. All summary transcripts were reviewed by two research team members. Following standard procedures for the treatment of qualitative data, thematic content analysis was used to identify themes that emerged in the interview and to assess how frequently these themes were expressed.

\section{Higher Education in Malaysia}

Higher education in Malaysia comprises of public and private higher education institutions. The public sector includes 20 universities, 33 polytechnics and 91 community colleges, while the private sector is made up of 70 universities, 34 university colleges and 410 colleges. Among the 20 public universities, five of them have been designated by the Ministry of Higher Education as research universities, and between 2007 and 2012, they have received a total sum of 1.863 billion MYR ( US\$ 0.45 billion) from the government to develop their research capabilities (MOE 2014). The remaining public universities are either categorized as comprehensive or specialized, where the latter are expected to develop niches in areas of education, defense, management or technical/engineering. It is fair to surmise that most private universities are not research-intensive institution where their primary focus is teaching as students especially undergraduates are their main source of revenues. In 2014, 48 percent of 1.2 million students in higher education were enrolled in public universities (MOE 2015). Another 42 percent of students were enrolled in private universities, university colleges and colleges. (The remaining $10 \%$ were enrolled in polytechnical and community colleges.) In terms of faculty, 49 percent were employed by the 20 public universities, while another 36 percent were based across 500 private higher education institutions.

\section{Findings}

Employment equity: Interviewees addressed equity in workload, compensation, and promotion in rank opportunities. In all three types of institutions, work expectations of academic staff are communicated through a Key Performance Indicator (KPIs) system, a cascade system through which each level of the Malaysian higher education system conveys its expectations to the administrative level below it. The Ministry establishes performance indicators for each public university; private universities develop their own KPIs. Across all the institutions, university administrators then establish performance indicators for each Faculty, Deans establish KPIs for each department, and Deans and Heads of Department (HOD) together determine the KPI for each academic staff member. University administrators argue that the KPI system ensures equity in how faculty performance is evaluated (Chapman and Chien 2015). They argue that it is fair because it applies the same expectations to all faculty members. Critics, however, believe that the system fails to accommodate differences across disciplines. All the interviewees in this study believed that their KPIs were clearly spelled out and well understood, though not all interviewees were clear about how their performance on the KPI criteria affected their conditions of employment. Interviewees raised three main issues related to employment equity: equity in workload, fairness in compensation, and fairness in the promotion process. 
Workload: While specific workloads vary by institution, field, and rank, there was similarity in the kind of work activities expected across all six institutions, with the exception of teaching load. The work expectation described by one interviewee reflects what was typical for most: Professors are expected to teach, publish three articles in international journals, present at two international conferences per year and have two funded projects. Associate professors are expected to teach, publish two articles in international journals, present at two international conferences per year, and have at least one consultancy project. Senior lectures are expected to teach, publish at least one article in an international journal, and present at one international conference per year. Lectures are expected to publish one journal article over two years and present at one international conference.

Interviewees at all six universities observed that the nature of faculty work has been changing in Malaysia, with faculty members under ever increasing pressure to do more research and increase their publication rates. For most interviewees, this shift in institutional priorities was the most salient aspect of their professional lives and for many (though not all) an unpleasant one. One reason was that, in the view of most interviewees, the growing workload did not lead to any greater personal or professional rewards (discussed below).

Interview data showed considerable variation in teaching loads by type of institution, as illustrated in Table 2. The average teaching load at private universities was nearly $240 \%$ of the teaching load at research universities. The discrepancy in teaching loads across institutional types, with faculty in private universities expected to carry higher teaching loads, fits a patterns described in the higher education literature as a 'striving university'(Gardner 2013; O'Meara and Bloomgarden 2007). These universities pursue prestige within the academic hierarchy by encouraging more faculty research, yet are still heavily tuition-dependent, so expect faculty members to continue to carry a heavy instructional load.

Table 2. Average teaching loads (number of students) by type of institution, instructor rank and gender

$(\mathrm{N}=50$ interviewees who responded to this question)

\begin{tabular}{lccccc}
\hline $\begin{array}{l}\text { Institutional } \\
\text { type }\end{array}$ & Private & Comprehensive & Research & Overall \\
\hline All respondents & Avg. teaching load & 200 & 111 & 82 & 116 \\
\hline & $\mathrm{N}$ & 10 & 18 & 22 & 50 \\
\hline Gender & & & & & \\
\hline Males & Avg. teaching load & 184 & 90 & 93 & \\
\hline & $\mathrm{N}$ & 7 & 10 & 15 \\
\hline Females & Avg. teaching load & 238 & 137 & 61 & \\
\hline & $\mathrm{N}$ & 3 & 8 & 7 & \\
\hline Academic Rank & & & & & \\
\hline Junior rank & Avg. teaching load & 209 & 98 & 83 \\
\hline & $\mathrm{N}$ & 5 & 7 & 11 \\
\hline Senior rank & Avg. teaching load & 192 & 119 & 83 \\
\hline & $\mathrm{N}$ & 5 & 11 & 11 \\
\hline
\end{tabular}

In private and comprehensive universities, females carry about a $30 \%$ higher teaching load than their male counterparts. This suggests that, in those institutions, female faculty members are trying to meet the same research, publication, and service expectations as men, while carrying a higher teaching load. Interestingly, this pattern was reversed at research universities, where the teaching loads of men were about $50 \%$ higher than for women. Teaching loads did not differ much based on rank. For the most part, academic staff at junior and senior ranks carried roughly the same teaching loads.

Incentives: Incentives can be both monetary and non-monetary. Monetary incentives include salary, fringe benefits, bonuses, and job security. Non-monetary incentives include such factors as public recognition, love of teaching, and general quality of life. Interviewees observed that, within the public universities in Malaysia, there were few 
meaningful monetary incentives for exceptional work. Faculty members at the same rank, hired in the same year, receive the same salary and same annual salary increase, regardless of performance. While this practice establishes parity across a given institution, interviewees did not view this as fair, since compensation levels did not recognize different levels of performance. Indeed, there are few mechanisms through which faculty members can be financially rewarded for outstanding work.

There are three mechanisms through which faculty members in public universities can receive additional income, other than salary. First, most public universities offer a financial bonus to faculty members for each journal article they publish in a top-level journal. While the amount varies by the competitiveness of the journal, the bonus for publishing in a top journal is in the range of 2000 MYR to 5000 MYR ( US\$480-\$1200) per journal article. Second, the universities have excellence awards, given to 1-5 people within each Faculty each year, each of whom received a one-time bonus of 1000 MYR (US\$312). Since some Faculties have over 100 instructors and staff competing for these awards, the incentive value of the award for most people is limited. Moreover, there is a quota on the number of awards available to be offered each year and those receiving an award are limited from receiving it again within a prescribed number of years (reported by some interviewees to be three years). Third, faculty can earn a promotion in rank which would then move them to a higher salary scale.

Interviewees in the public universities expressed mixed views about how university salaries compared with their private sector alternatives. In most fields, academic salaries were deemed to be generally comparable to off-campus options that were realistically available to them, but carried fringe benefits, notably job security and pension benefits, that made university employment more attractive. Interviewees' actions supported that view; many had 'voted with their feet' in choosing to work at a university. A substantial number of faculty members had moved into university teaching after working in private sector enterprises. They knew what they were missing.

Salaries at private universities followed a different pattern in which entry salaries are negotiable at the time of hiring, based on experience and background. In general, interviewees at the private universities reported that their salaries were lower than their counterparts at public universities and that they did not have the same job security. However, annual salary increases vary by individual and are performance-based. At PU-1, all faculty members have KPIs. They complete an annual performance report detailing their teaching and advising load, research productivity, community engagement, and amount of funding secured. These reports are scored on a point system, in which some pointed are allocated based on activities completed and recognized achievements and some are based on the Head of Department's and Dean's personal evaluation of the individual. Faculty members can receive up to an additional full month of salary as a bonus for being high in their annual rankings. This is not a change in base salary; faculty members compete again the next year to secure the extra salary.

Promotion in rank: While the use of the KPI system was generally viewed as equitable in the annual review process, that positive regard did not extend to its application in the faculty promotion process. In the promotion process, 10-20 percent of the annual score is reserved for a subjective assessment by the Head of Department (HOD) and Dean. While faculty members generally appreciate the transparency provided by the quantitative portion of the annual review, they were concerned that the criteria and reasons for their ratings on the subjective dimension are sometimes not clear. Many faculty in the public universities felt that the promotion system lacked transparency and did not yield fair treatment, reaffirming a findings reported by Azman and colleagues (2016). Those interviewees most critical of the process tended to be males, those in Comprehensive Universities, and those at senior ranks (Table 3). Interviewees in public universities more often voiced a criticism of the promotion process; relatively few interviewees in the private universities commented on it.

Another factor fueling the perceived unfairness of the promotion process, particularly at comprehensive universities, is the requirement that a faculty member needs to advise a $\mathrm{PhD}$ student through graduation before applying for promotion. Interviewees observed that there are not many doctoral students at comprehensive universities and that those universities tend to get weaker graduate students (than do research universities) so it takes them longer to complete their doctorates. The lack of doctoral students to advise limits the eligibility of some faculty for promotion, and this factor underlined by institutional differences can be considered a new finding as Malaysian public universities adopt one common grade and salary scheme and few studies have devoted into examining institutional differences within this common scheme. 
Table 3. Malaysian academic staff views of the promotion process

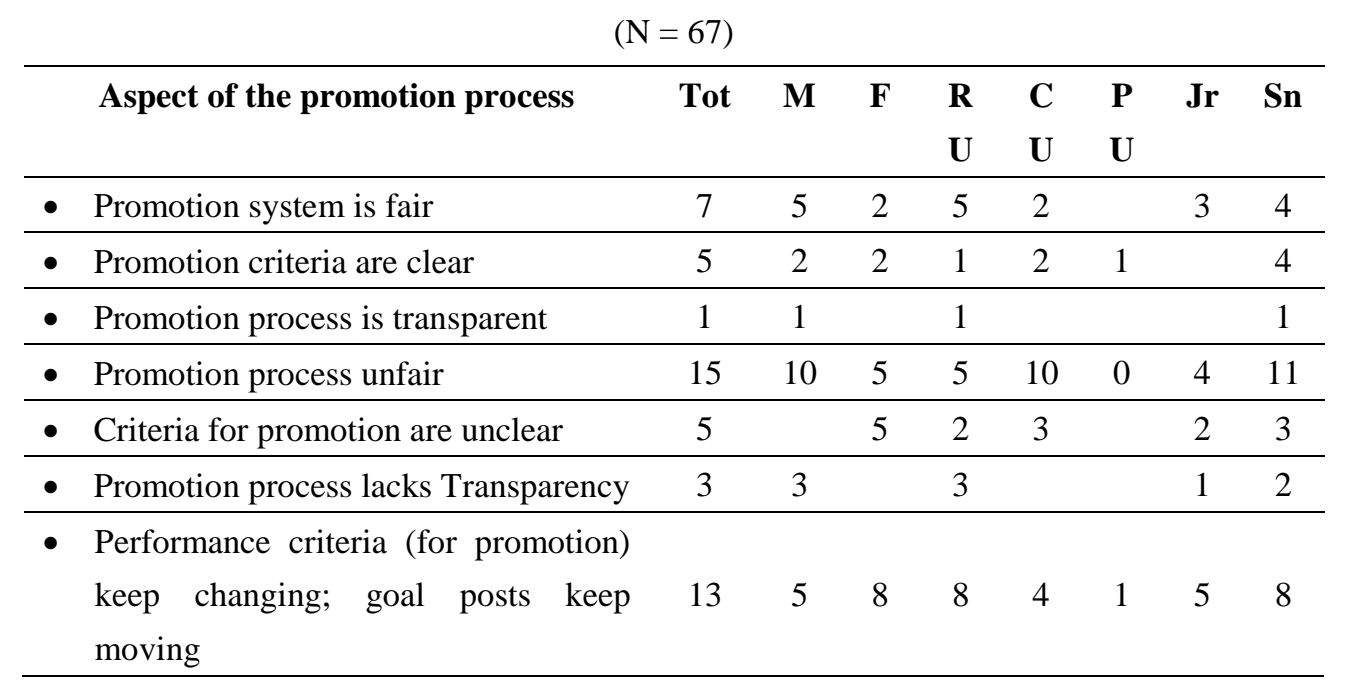

Academic freedom and autonomy: When asked about their range of professional autonomy as academic staff, responses pertained to four general areas--autonomy in selection of course content, pedagogical methods, research topics, and their control over their professional time. Virtually all respondents reported that they do not have much freedom to choose the content of their courses because they have to follow the syllabi approved by their university Senate, the Malaysian Qualifications Agency (MQA), and the Ministry of Education. The one exception is that instructors teaching highly advanced courses in specialized areas in which there is not a Ministry proscribed curriculum indicated they had flexibility in determining their own course content. The universities review their curriculum annually but change it only once every five years. In some fields and at some universities, interviewees indicated that they had the flexibility to change $20-30 \%$ of the content of their course without needing higher level approval.

Decisions about pedagogical methods are left to each instructor. Respondents agreed that they have considerable freedom to determine the teaching methods that they will use in delivering their instruction. Similarly, virtually all respondents agreed that they can determine their own research topics. The primary constraint on their choice of research topic is the availability of funding to support their work, but access to funding is determined more by the quality of their proposal than by any censorship or political concerns. Overall, academic staff seemed satisfied with the range of flexibility and control they had over their teaching and, for the most part, over their research.

Flexibility refers to faculty members' ability to adjust their work arrangements in ways that maximize their contributions to their institutions and to the meaningfulness of their work and personal lives. Interviewees' experiences varied widely across institutions, less related to institutional type than to the administrative style of the leadership of the particular department or faculty in which the interviewee was located. For the most part, interviewees said they had flexibility in their working hours, as long as their classes and student consultation hours were met. For the most part, they could determine how to allocate their time among their research, teaching, and other duties, as long as they meet their teaching responsibilities. Others, albeit a minority, said they had to 'punch in' and were expected to be in their campus offices during the full workday. For these faculty members, the lack of flexibility in time management was a salient factor contributing to discontent.

Professional growth: Interviews indicated that all of the universities in this study had well-developed professional development programs which were widely considered by academic staff to be helpful and effective. Five of the six universities had an initial orientation for new faculty members. All had mentoring programs in which junior faculty members were paired with senior faculty members, though this was sometimes managed at the faculty or departmental levels. All six universities offered a professional development course of between 20-40 hours duration (depending on the university) designed to assist instructors in the development and delivery of their courses. Participation in these programs was mandatory for new instructional staff but open to others who wished to bolster their teaching skills. In addition, all of the universities sponsored an on-going set of optional workshops, lectures, and professional consultations to support instructional staff who wished to further develop their pedagogical skills. One of the universities went further, requiring all faculty members to participate in at least 30 hours a year in 
professional development activities, but offered a range of activities from which the faculty members could choose. Beyond teaching support, the universities also offered limited research funds, awarded on a competitive basis. Five of the six universities offered financial support for academic staff to attend professional conferences, though such awards were competitive, limited in number, and specific rules varied. Public universities generally give sabbatical leaves to all faculty members whereas sabbatical leaves in private universities are available but harder to get.

Collegiality: A considerably higher proportion of faculty in public comprehensive and private universities (as opposed to research universities) characterized faculty relationships on their campus as friendly, supportive, and collaborative. In contrast, most faculty at research universities said they did not collaborate with campus colleagues or, if they did, the collaboration was narrowly professional in nature and not motivated by personal friendship (Table 4).

Another dimension of collegiality concerns the role of faculty members in university governance. Across all three types of universities, interviewees reported that governance is top-down, with power and authority concentrated at the level of the Vice Chancellor. When a Vice Chancellor changes, institutional priorities can change abruptly. Interviewees at one private university described the university as having two phases since its founding, defined by the priorities of the two vice chancellors. Under the university's first Vice Chancellor, faculty members were expected to emphasize teaching and program development. Tuition was the primary income source of the university and it needed to attract enough students to generate sufficient tuition to cover costs. The second Vice Chancellor assigned greater importance to research as a way of raising the visibility and stature of the University within the country and beyond. Criteria for promotion changed abruptly and, in the view of interviewees, this change disadvantaged faculty members who had been working to meet the criteria set by the first Vice Chancellor. Pressures to increase research productivity changed the nature of the work experience for the faculty.

Table 4. Interviewees' reflections on collegiality and collaboration

\begin{tabular}{|c|c|c|c|c|}
\hline Extent of collegiality & Tot & RU & $\mathbf{C U}$ & PU \\
\hline $\begin{array}{l}\text { - Work setting characterized by strong personal friendships; } \\
\text { friendly supportive work environment; Good collaboration } \\
\text { among colleagues }\end{array}$ & 16 & 3 & 7 & 6 \\
\hline $\begin{array}{l}\text { - Faculty interests interact more as professional colleagues } \\
\text { than as personal friends; people get along with each other } \\
\text { well, but don't collaborate much; does not collaborate with } \\
\text { campus colleagues }\end{array}$ & 20 & 13 & 5 & 2 \\
\hline - A mixture: some colleagues collaborate, some don't & 7 & 2 & 3 & 2 \\
\hline \multicolumn{5}{|l|}{ Pattern of Collaboration } \\
\hline $\begin{array}{l}\text { - Collaboration tends to be within subgroups, e.g., } \\
\text { racial/ethnic identities (4); research specialties (2); gender } \\
\text { (2); academic rank (2); with former advisor (2); children (1); } \\
\text { departmental structure (1) }\end{array}$ & 14 & 2 & 8 & 4 \\
\hline - Collaboration occurs around teaching, less around research & 6 & 2 & 2 & 2 \\
\hline \multicolumn{5}{|l|}{\begin{tabular}{|l|} 
Factors promoting collaboration \\
\end{tabular}} \\
\hline $\begin{array}{l}\text { - Regular faculty meetings; occasional social functions help } \\
\text { build collegiality }\end{array}$ & 3 & 0 & 1 & 2 \\
\hline $\begin{array}{l}\text { - Mentoring programs (senior instructor working with junior } \\
\text { instructor) }\end{array}$ & 3 & 0 & 2 & 1 \\
\hline - Shared office space & 2 & 0 & 0 & 2 \\
\hline - Pressure to publish promotes collaboration & 1 & 1 & 0 & 0 \\
\hline
\end{tabular}

Factors inhibiting collaboration 


\begin{tabular}{lllll}
\hline $\begin{array}{l}\text { - Collaboration can lead being exploited (e.g., plagiarism, } \\
\text { gift authorship) }\end{array}$ & 4 & 0 & 3 & 1 \\
\hline - Time, work pressure, and competition with colleagues for & 3 & 2 & 1 & 0 \\
$\begin{array}{l}\text { resources limit collaboration } \\
\text { - Academic staff can ask for help from head of department } \\
\text { or Dean as needed }\end{array}$ & 4 & 0 & 0 & 4 \\
\hline - Jealousy, envy, office politics & 1 & 1 & 0 & 0 \\
\hline
\end{tabular}

\section{Conclusion}

Findings support the claim that the pursuit of excellence in Malaysian higher education is placing new demands on academic staff that are affecting the way they view their work and their careers, although the reaction of faculty members differs to some extent by the type of institution in which they are located. When findings are considered through the lens of the Gappa et al., framework, those in academic careers within Malaysian universities generally fare well. Faculty members generally felt that they had adequate academic freedom and autonomy and most felt they had sufficient flexibility in their work setting. Where flexibility was constrained, it was most often due to the behavior of individual managers and not endemic to the institution. Professional growth opportunities, at least when understood as access to faculty development support, were readily available at all the universities. For the most part, faculty members believed there were high levels of collegiality, though there were notable differences across university types, with the least collegiality evidenced at research universities.

The area of greatest discontent concerned employment equity. In the emphasis on parity (e.g., similar expectations for KPIs across faculty members), equity was compromised as differences in productivity were not adequately acknowledged or rewarded. Faculty members acknowledged that KPIs are clearly stated and consistent across academic staff and, in that sense 'fair'. However, they were distressed that personal performance seems disconnected from rewards. Harder work does not yield greater financial payoff. This is a particularly salient issue at a time when academic staff are, for the most part, being asked to work harder and be more productive.

From the lens of job characteristics theory, findings suggest that, even though academic staff have a generally positive view of their work setting, many faculty members, particularly at private and comprehensive universities, are concerned about the changing nature of their work lives. While the intensified push for research is widely accepted, even welcomed, by academic staff at research universities, it is less well received at public comprehensive and private universities. At these types of universities, many academic staff remain uncertain about whether they are able, or want, to meet the expectations for increased research productivity. This ambivalence arises, in part, because they are expected to increase their publication rate while still being expected to meet the previous teaching expectations.

While, for the most part, faculty members at these six Malaysian universities are adapting well to the new pressures for productivity, there is a widespread view that the increasing external pressures on universities and, in turn, on academic staff, are reshaping the nature of academic work lives in ways that are not widely welcomed. Some discontent around increasing workload, in the form of heightened research expectations, was expressed by faculty members interviewed for this study. The central issue across all six institutions is that the increased demand for research and publication viewed by government and university managers as the pathway to excellence is, in the view of many faculty members, largely disconnected from a meaningful or equitable reward structure. Based on their review of relevant research studies, Gappa et al. (2007) argued that the presence of key elements of academic work--including equity, as well as autonomy, flexibility, professional growth, and collegiality--relate to faculty satisfaction, sense of meaningfulness, and commitment to institutional missions. If academic staff have concerns about equity in the workplace, particularly because they find that the reward structure does not match workload expectations, they may become discontent, dissatisfied, and disengaged. Heightened pressure for more research coupled with inadequate rewards for this work can also lead to less quality in the research produced, as well as, potentially, to less faculty attention to institution's teaching mission.

For the context of Malaysian higher education, this study demonstrated subtle differences on the academic profession across different types of universities. These differences, either between public and private universities, or between public research and comprehensive universities, underline the need to take into account the type of university in shaping the academic profession and other aspects of higher education. 
Although this study is limited to selected higher education institutions in Malaysia, the findings have wider implications in contributing to the understanding of faculty work, academic culture, and decision making in the broader context of higher education in countries aggressively seeking to raise the international rankings of their universities. First, workload expectations cannot be decoupled from attention to the incentive system, including compensation and intrinsic rewards. Second, a seemingly logical and direct policy choice designed to achieve greater international prestige for the institution may have unintended consequences and be less strategic and effective than intended. Third, for university leaders who want their institutions to achieve world-class status, the path involves not only raising the expectations facing individual academic staff, but also ensuring that the institution creates an environment that provides the key elements that make academic work satisfying, meaningful, and fair.

\section{References}

Austin, A., Chapman. D.W., Farah, S., Wilson, E., \& Ridge, N. (2014). Expatriate academic staff in the United Arab Emirates: the nature of their work experiences in higher education institutions. Higher Education, 68, 541-557, https://doi.org/10.1007/s10734-014-9727-z

Azman, N., \& Mydin Kutty, F. (2016). Imposing global university rankings on local academic culture: Insights from the National University of Malaysia. In M. Yudkevich, P.G. Altbach \& L.E. Rumbley (Eds.), The Global Academic Rankings Game: Changing Institutional Policy, Practice and Academic Life (pp. 97-123). New York: Routledge.

Azman, N., Che Omar, I., Md Yunus, A.S., \& Md Zain, A.N. (2016). Academic promotion in Malaysian public universities: A critical look at issues and challenges. Oxford Review of Education, 42, 1. https://doi.org/10.1080/03054985.2015.1135114

Azman, N., Pang, V., Sirat, M., \& Md Yunus. (2014). Teaching and Research in Malaysian Public Universities: Synergistic or Anatagonistic?. In J.C. Shin, A. Arimoto, W.K. Cummings and U. Teichler (Eds.), Teaching and Research in Contemporary Higher Education: Systems, Activities and Rewards (pp. 255-276). London: Springer.

Azman, N., Sirat, M., \& Dahalan, N. (2012). The academic promotion process in Malaysian public universities: In search of best practices. Journal of the World Universities Forum, 4, 19-35.

Chapman, D.W., \& Chien, C-L. (2015). Expanding Up After Expanding Out: Graduate Education in Malaysia and Thailand. Higher Education Studies, 5, 3. https://doi.org/10.5539/hes.v5n3p1

Faturochman. (1997, December). The Job Characteristics Theory: A Review. Buletin Psikologi., 2, 1-13.

Gappa, J. M., Austin, A. E., \& Trice, A. G. (2007). Rethinking Faculty Work: Higher Education's Strategies Imperative. San Francisco: Jossey-Bass.

Gardner, S. K. (2013). Women Faculty Departures from a Striving Institution: Between a Rock and a Hard Place. Review of Higher Education, 36(3), 349-370.

Hassan, A., Tymms, P., \& Ismail, H. (2008). Academic productivity as perceived by Malaysian academics. Journal of Higher Education Policy and Management, 30(3), 283-296. https://doi.org/10.1080/13600800802155184

Marmolejo, F. (2015). Are we obsessed with university rankings? Education for Global Development Blog, Washington D.C.: $\quad$ World Bank. http://blogs.worldbank.org/education/are-we-obsessed-university-rankings

Ministry of Education (MOE). (2014). Impact of Malaysian Research Universities as the Engine of Growth for Nation Building: Research Report. Bandar Baru Nilai: USIM Publisher.

Ministry of Education (MOE). (2015). Malaysia Education Blueprint 2015-2025 (Higher Education). Putrajaya: Ministry of Education.

O'Meara, K.A., \& Bloomgarden, A. (2011). The pursuit of prestige: the experience of institutional striving from a faculty perspective. The Journal of the Professoriate, 4(1), 39-73.

Philip G. A. (2012). The Globalization of College and University Rankings. Change: The Magazine of Higher Learning, 44(1), 26-31. https://doi.org/10.1080/00091383.2012.636001

Sirat, M., Azman, N., \& Wan, C.D. (2017). The dilemma of university rankings in policy and policymaking: The Malaysian experience. In E. Hazelkorn (Ed.), Global Rankings and the Geopolitics of Higher Education: 
Understanding the influence and impact of rankings on higher education, policy and society (pp. 77-99). New York: Routledge.

UNESCO Institute for Statistics. (2014). Higher Education in East and Southeast Asia: Expand Out, Expanding Up, Montreal: UNESCO Institute of Statistics, Chapman, David W. \& Chien, Chiao-Ling, (Eds.).

Wan, C.D., Chapman, D., Hutcheson, S., Lee, M., Austin, A., \& Md. Zain A. (2016). Changing higher education practice in Malaysia: The conundrum of incentives. Studies in Higher Education. https://doi.org/10.1080/03075079.2015.1134475

Wan, C.D., Md. Zain, A., Chapman, D., Lee, M., Austin, A., \& Hutcheson, S. (2015). Academic Culture in Malaysia: Sources of satisfaction and frustration. Asia Pacific Education Review, $16,4$. https://doi.org/10.1007/s12564-015-9398-1 